\title{
Vital Cuinet'e Göre XIX. Yüzyıl Sonlarında Balıkesir'in İdari, Demografik ve Sosyo-Ekonomik Yapısı
}

\author{
Şenay Atama, b
}

\section{Özet}

Anadolu Selçuklu Devleti'nin zayıflaması ile bir dönem Karesi Beyliği'nin merkezi olan Balıkesir, Orhan Bey zamanında Osmanlı Devleti'nin hâkimiyetine girmiştir. Yeraltı zenginlikleri, özellikle dokumacılık, deri sanayisi ve ormanları bakımından Osmanlı ekonomisinde önemli bir yere sahip olan Balıkesir, Osmanlı idarî teşkilatında önce Anadolu eyaletine, daha sonra ise Hüdavendigâr Vilayeti'ne bağlı bulunan Karesi Sancağının merkezi olmuştur. 1880-1892 yılları arasında Düyûn-1 Umumiye İdaresi Genel Sekreteri olan Vital Cuinet, bu görevi esnasında Anadolu'yu gezerek Osmanlı Devleti'nin sosyo-ekonomik, demografik ve idarî yapısını incelemiştir. Elde ettiği izlenim ve verileri ise bir kitap haline getirmiştir. Eser, Paris'te 1892 yılında "La Turque D'Asie, Géographie Administrative Statistique Descritive et Raisonnée De L'asie-Mineure" adıyla dört cilt olarak basılmıştır. Balıkesir şehrini muhtemelen 1891 yılında ziyaret eden Cuinet'in şehre dair elde ettiği bilgiler eserin dördüncü cildinde yer almaktadır. Bu çalışmada Cuinet'in Balıkesir'e dair verdiği bilgiler esas alınarak şehrin XIX. yüzyıl sonlarındaki sosyo-ekonomik, demografik ve idarî yapısı ortaya konulmuştur.
Anahtar Kelimeler

Balıkesir

Cuinet

Karesi

Osmanl

Makale Hakkında

Geliş Tarihi: 02.01.2020

Kabul Tarihi: 25.12.2020

Doi: 10.18026/cbayarsos.669200

\section{According to Vital Cuinet, Administrative, Demographic and Socio-Economic Structure of Balıkesir at the end of the XIX ${ }^{\text {th }}$ Century}

Abstract

With the weakening of the Anatolian Seljuk State, Balıkesir, which was the center of the Karesi Principality for a period, came under the domination of the Ottoman Empire during the time of Orhan Bey. Balıkesir, which had an important place in the Ottoman economy in terms of underground riches, especially weaving, leather industry and forests, became the center of the Karesi Sanjak, which was connected to the province of Anatolia first and then to the Hudavendigar Province in the Ottoman administrative organization. Vital Cuinet, who served as the General Secretary of the Ottoman Public Debt Administration from 1880 to 1892, visited Anatolia during this duty and examined the socio-economic, demographic and administrative structure of the Ottoman Empire. He had compiled the impressions and data it obtained into a book. The work was published in Paris in 1892 with the name "La Turque D'Asie, Géographie Administrative Statistique Descritive et Raisonnée De L'asie-Mineure" in four volumes. The information obtained by Cuinet, who visited Balıkesir city in 1891, is included in the fourth volume of the work. In this study, the socio-economic structure of the city at the end of the XIXth century has been revealed based on the information of Cuinet about Balıkesir.
Keywords

Balikesir

Cuinet

Karesi

Ottoman

About Article

Received: 02.01.2020

Accepted: 25.12.2020

Doi: $10.18026 /$ cbayarsos.669200

a senayatam@osmaniye.edu.tr.

b Dr. Öğr. Üyesi, Osmaniye Korkut Ata Üniversitesi Fen-Edebiyat Fakültesi, Tarih Bölümü, ORCID ID: 0000-0001-8672-3063 


\section{Giriş}

1853-1856 Osmanlı-Rus Savaşı esnasında ekonominin sıkıntıya girmesi ve Osmanlı Devleti'ni borçlandırarak mali anlamda denetime tabi tutmak isteyen İngiltere ve Fransa'nın teşviki neticesinde, Osmanlı Devleti 1854 yılında ilk dış borçlanmasını gerçekleştirmiştir. Osmanlı maliyesi, bundan sonra rahat bir nefes alamamış, tıkandığı noktalarda dış borçlanmayı çözüm olarak görmeye başlamıştır. 1854-1874 yılları arasında yaşanan bu hizlı borçlanma süreci sonrasında Osmanlı ekonomisi iflas etmiş ve borçların ödenmesi ile ilgili ilk olarak 6 Ekim 1875 tarihinde bir kararname yayınlamıştır. Avrupalı alacaklıların tepkisi neticesinde borçların ödenebilmesi için önce Rüsum-1 Sitte İdaresi kurulmuştur. Sonradan Avrupalı devletlerin Osmanlı Devleti'ne baskılarıyla bu idare kaldırılarak yerine 20 Aralık 1881 tarihinde Düyûn-1 Umumiye İdaresi tesis edilmiştir. Bu idarenin bir meclisi vardır ve başkanlığı Fransız ve İngiliz temsilcilerine aittir (Küçük ve Ertüzün, 1994: 58-60; Gürsoy, 1984: 17-59; Pamuk, 2018: 56-63; Birdal, 2010: 53-62).

Vital Cuinet, (1833-1896) Düyûn-1 Umumiye tarafından müfettiş olarak 1880-1892 yılları arasında Osmanlı İmparatorluğu'nun gelir kaynaklarını tespit etmek ve envanterlerini çıkartmak için görevlendirilmiştir. Verilen bu görev Cuinet'e Osmanlı Devleti'nin Asya topraklarında yer alan vilayetlerinde idarî yönetim, yeraltı zenginlikleri, nüfusu, yolları, ormanları, tarımsal ve ticarî faaliyetleri gibi bilgileri toparlamasını sağlamıştır. On iki yıl boyunca Osmanlı topraklarında kalan Vital Cuinet'in yaptığı bu çalışmalar daha sonraları 1892'de Paris'te, La Turquie d'Asie Géographie Administrative ismi altında kitap olarak yayımlanmıştır. Cuinet'in bu eseri hazırlaması da elbette sadece bir devletin idarî, ekonomik ve sosyal yapısını ortaya koymak maksadıyla masumane niyetle yapılmış kültürel bir faaliyet değildir. Osmanlı Devleti'nde demiryollarından, madene, elektriğe varıncaya kadar birçok alanda yatırımları (Issawi, 1982: 69) olan ve nüfuz alanını daha da fazla genişletmek isteyen Fransa'nın eserin hazırlanması aşamasındaki desteği açıktır. Cuinet'in o dönem için yaptığı çalışma, günümüzde Osmanlı Devleti'nin XIX. yüzyıl sonlarında şehirlerdeki sosyalekonomik, idarî yapıyı ortaya koyması bakımından mühimdir. Son zamanlarda da şehir tarihi araştırmalarında bu esere dayalı olarak yapılan bir takım çalışmalar mevcuttur (Töreli, 2020: 763-774; Çakmak, 2020: 22-37; Atam ve Candeğer, 2019: 249-260).

Cuinet, eserinin giriş bölümünde eserini hangi metotlarla hazırladığını açıklamıştır. Eserini hazırlamak için on iki yıl boyunca Anadolu'ya seyahatler düzenlemiştir. Diğer seyyahların gezilerini turistik amaçla yaptıklarından dolayı eserlerinde kendi kişisel duygularına yer verdiklerini ve bu bakımdan çok da güvenilir olmadıklarını eserinde belirtmiştir. Elindeki bu değerli bilgileri doküman olarak ortaya koymadan önce yerinde incelemelerde bulunduğunu, isimlerini açıklayamayacağı bazı kişilerden de faydalandığını ifade etmiştir. Zaman zaman da istatistikî bilgiler veren salnamelerden faydalanmıştır (Cuinet, IV, 1894: 256). Cuinet, bu projeyi başlattığında Osmanlı Devleti'nde yayınlanmış olan salnamelerin haricinde hiçbir resmi kayda dayanamadığını ve salnamelerde yer alan istatistiklerin de çoğu zaman eksik ve yanlışlıklarla dolu olduğunu belirtmiştir. Salnamelerdeki nüfus sayımlarının bile yayımlandığı yıla değil dört yıl önceki istatistiklere ait olduğunu, cinsiyet veya mezheplerden hiç bahsedilmediğini, kendisinin ise buna ayrıca özen gösterdiğini ifade etmiştir. Ayrıca okul istatistikleri, ülkenin doğal üretimleri, sanayi, ticaret, ithalat, ulaşım gibi konularda da sınıflandırmalara dikkat ettiğini vurgulamıştır. Osmanlı Devleti'nde son zamanlarda istatistikler yayınlanmaya başlansa da bu istatistikî verilerden, devletin bir vilayetinin ürünleri, kaynakları veya ihtiyaçları hakkında bilgi edinilemeyeceği konusu 
üzerinde özellikle durmuştur. Cuinet, çalışmasını gerçekleştirirken geçmişle bugün arasında bağlantıyı kurabilmek için her ziyaret ettiği yerde kamu ve özel kütüphaneleri ziyaret ettiğini, okuyuculara titiz bir çalışmanın ürünü olarak güvenilir bir eser sunduğunu belirtmiştir (Cuinet, I, 1894: I-VIII). Yaptığı bu çalışmalar neticesinde XIX. yüzyılda Osmanlı Devleti'nin Trabzon, Erzurum, Bitlis, Sivas, Ankara, Adana, Bağdat, Basra, Halep, Cezayir-i Bahr-i Sefid, Diyarbekir, Van, Musul, Girit, İzmir, Kastamonu, Bursa, İstanbul vilayetlerinde sancak ve kazaların yönetim, nüfus, idarî, etnik, dinî, coğrafî ve sosyo-ekonomik yapısı ile üretim gelirlerini ortaya koymuştur (Toruk, 2009: 724). Her ne kadar verdiği bilgilerin "taraflı" ya da "hatalı" içerikler oluşturduğuna dair çalışmalar mevcut ise de (Tellioğlu, 1998: 102) öncelikle yapılması gereken bu eserdeki verilerin ortaya konulması ve ardından Osmanlı'daki kayıtlarla karşılaştırılmasıdır. Hatta bu karşılaştırma bizzat Osmanlı makamlarınca dahi Kilis'in işgali esnasında yapılmıştır. Halep Vilayet Salnamesi ve Vital Cuinet'in eserinin verdiği bilgilere dayanarak Kilis'in nüfusunun Türk olduğu ve Osmanlı' da kalması gerektiği savunulmuştur (BOA, DH.KMS., 51/9, 20 Şaban 1337, 21 Mayıs 1919).

\section{Cuinet'e Göre Balıkesir}

\section{A. Balıkesir'in İdaresi}

Cuinet, Balıkesir şehrini tanımlarken Yılan Dağı'nın eteklerinde geniş ve bereketli adını bu dağdan alan bir ovada kurulu, iklimi mükemmel, her tarafı üzüm bağları ve çeşit çeşit lezzetli meyve ve yemişle dolu bir yer tabirini kullanmıştır. Taze yeşillik göz alabildiğine uzanırken birden buğday tarlaları arasından sevimli köylerin çıkıverdiğini vurgulamıştır (Cuinet, IV, 1894: 264).

İdari bakımdan Balıkesir, 1864 vilayet düzenlemesi ile birlikte Hüdavendigar Vilayetine bağlı sancak olan Karesi'nin merkezidir (Çadırcı, 1997: 368; Baykara, 2000: 121). Karesi Sancağı, ulaşım bakımından limanları ile Batı'ya açılabilmesi, bunun yanı sıra yeraltı zenginlikleri, tarım ve hayvancılığı, dokumacılık sektörü nedeniyle yerli ve yabancı tüccarların yoğun faaliyet gösterdiği bir alan olması nedeniyle günden güne önemi artan bir konuma gelmiştir. Hatta bölgede bor madeninin keşfi neticesinde bölge yabancı firmaların ve bağlı oldukları devletlerin ilgi odağı haline gelmiş, bir süre ayrı vilayet olarak idaresi söz konusu olmuştur. Bölge halkının uğraştığı alanlar da buna paralel olarak çeşitlilik arz etmiştir.

Cuinet'in verdiği bilgilere göre Balıkesir, sancağın merkezi ve merkez kazası olarak mutasarrıfın idaresindedir. Ayrıca şehirde bulunan gayrimüslim cemaat liderlerinin de üyesi olduğu Kaza İdare Meclisinin merkezi buradadır. Rum Ortodoks ve Gregoryen Ermeni cemaati hukukçularının bulunduğu hukuk, sulh, ceza ve bidayet (modern hukuk) mahkemelerinin ve şer'i (Müslüman) mahkemesinin de merkezi olup imparatorluk davacı vekilinin de ikametgâhı burasıdır. Burada maden, orman, posta-telgraf yönetimi; bir belediye; hayır işleri, eğitim, sanat ve meslek gibi konularla ilgili komisyonlar; bir tarım bankası, tütün reji yönetimi; polis teşkilatı, memur yetiştirmek için açılmış bir yüksekokul (mülkiye), bir lise vb. kurumlar mevcuttur. Bunlardan başka hükümet konağı, belediye binası, askeri binalar, sivil okullar, devlet liseleri, hapishane gibi kamu binaları mevcuttur. Şehir ve civarında 91 adet minareli cami ve mescit, eski bir meydan saat kulesi, fakir öğrencilerin beslendiği ve barındığı bir imaret, 2 anıtsal çeşme, 21 medrese, 6 adet 
Selçuklulardan kalma hamam ve yine bu dönemden kalma üstü tonozlu bir çarş1 bulunmaktadır. Balıkesir'de 845 butik (mağaza), 10 han, 18 ekmek fırını ve 2.742 ev sayılmıştır. Şehrin civarında 115 değirmen, 3 un deposu, 78 tabakhane vardır. Yüzölçümü 15.200 km2 olan Karesi Sancağ1 idarî bakımdan 9 kaza, 17 nahiye ve 943 köyden oluşmaktadır. Sancaktaki kaza, nahiye ve köy dağılımı aşağıdaki tabloda olduğu gibidir:

Tablo 1. Karesi Sancağı İdari Taksimatı

\begin{tabular}{|c|c|c|c|}
\hline Kazalar & Nahiyeler & Köyler & $\begin{array}{l}\text { Salnamelerdeki } \\
\text { Köy Sayıları }\end{array}$ \\
\hline Balıkesir & $\begin{array}{c}\text { Balıkesir, } \\
\text { Balya, İvrindi, } \\
\text { Giresun, Kepsut, } \\
\text { Firt, Balat }\end{array}$ & 423 & 408 \\
\hline Ayvalık & (Nahiyesiz) & 41 & 1 \\
\hline Kemer-Edremit & (Nahiyesiz) & 41 & 40 \\
\hline Edremit & $\begin{array}{c}\text { Edremit, } \\
\text { Armutova, } \\
\text { Avniye, Erdek, } \\
\text { Kapıdağ, Paşa }\end{array}$ & 123 & 122 \\
\hline Erdek & $\begin{array}{l}\text { Liman, } \\
\text { Marmara }\end{array}$ & 34 & 31 \\
\hline Gönen & (Nahiyesiz) & 51 & 52 \\
\hline Bandirma & $\begin{array}{l}\text { Bandırma, } \\
\text { Aydıncık, } \\
\text { Manyas }\end{array}$ & 89 & 85 \\
\hline Bigadiç & (Nahiyesiz) & 51 & 52 \\
\hline Sindirg1 & (Nahiyesiz) & 68 & 66 \\
\hline 9 Kaza & 17 Nahiye & 943 Köy & 874 Köy \\
\hline
\end{tabular}

\section{B. Balıkesir Nahiyeleri}

Cuinet, Balıkesir nahiyeleri hakkında da kısaca bilgiler sunmuştur (Cuinet, IV, 1894: 266). Buna göre;

Balya nahiyesinde 21.834'ü Müslüman, 346'sı Rum Ortodoks, 1.577'si muhacir veya Bulgar sığınmacı olmak üzere toplam 23.757 kişi yaşamaktadır. Bu muhacirlerin büyük çoğunluğu bölgedeki ormanlarda kurdukları ilkel hızarları işletmektedirler. Bu ormanların yüzölçümü yaklaşık 5.000 hektardır. Balya nahiyesinde 35 köyde hem tarım hem de ormana üleştirilmiş toplam 18.286 hektar alan vardır. Bu nahiyenin İlidya (llıca) köyünde hastaların şifa bulduğu meşhur bir kaplıca bulunmaktadır. Cuinet'in verdiği istatistikî bilgiler 1307 Hüdavendigar Vilayet Salnamesindeki ile birebir örtüşmektedir (HVS, 1307: 135-136). Cuinet'in farklı olarak verdiği bilgi ise bölgede bulunan muhacirlerin yaptığı iş ile alakalı olandır. 1310 
Hüdavendigar Vilayet Salnamesinde nahiyede Kocagümüş Madeni adında simli kurşun madeninin 99 yıllığına Fransız tebaasından Mösyö Rayzrayken'e verildiği belirtilmiştir. Bu Fransız, imtiyaz hakkını Lavlarium Kumpanyasına satmış ve bu şirket 10-11 yıl kazan ve makineler getirerek madeni işletmiştir. Salnamede şirketin işletme hakkını Fransız sermayedarlarından birine satarak "Osmanlı Balya Madeni Şirketi” olarak adının değiştiği ifade edilmiştir (Hüdavendigar Vilayeti Salnamesi, 1310: 424-426). 1305 Karesi Vilayeti Salnamesi ise nahiyedeki tarım ürünleri ve hayvancılık hakkında daha detaylı bilgiler vermektedir. Buna göre 184.500 dönüm arazi üzerinde yıllık 45.000 kile (bir kile ortalama $25,25 \mathrm{~kg}$ ) buğday, 42.700 kile arpa, 22.000 kile çavdar, 12.000 kile yulaf, 25.000 kile burçak, 25.800 kile nohut, 22.300 kile misır darısı, 6.950 kile palamut, bir miktar ceviz, badem, haşhaş ve susam üretimi yapılmaktadır. Ayrıca nahiyede 5.525 karasığır, 4.350 manda, 3.500 beygir vardır (Mutaf, 1997: 173).

İvrindi nahiyesinde minareli 3 camii, 1 medrese, 1 kilise, 1 okul, 3 han veya otel ve 15 butik bulunmaktadır. Bu bilgiler Hüdavendigar Vilayet Salnamesindekilerle aynıdır. Cuinet'e göre bütün nahiyede 67 köy, 12.053'ü Müslüman 265'i Rum Ortodoks olmak üzere toplam 12.348 kişi yaşamaktadır. 63 değirmen, 76 mağaza, 25 okul, 1 hamam ve 2.472 tane ev bulunmaktadır. Toprak çok verimli ve iyi işlenmiş durumdadır ve bol ürün vermektedir. Nahiyede pek çok maden bulunmaktadır. İvrindi'ye $22 \mathrm{~km}$ mesafede çok tesirli denilen sülfürlü bir kaplıca mevcuttur. Cuinet'in verdiği bilgiler ile 1307 Hüdavendigar Vilayet Salnamesinde verdiği bilgiler örtüşmektedir (HVS, 1307: 136). 1310 Hüdavendigar Vilayet Salnamesindeki bilgiler ile kıyaslandığında ufak farklılıklar bulunmaktadır. Değirmen ve dükkân sayıları aynı olup, okul sayısı ise salnameye göre yeni açılanlarla birlikte $45^{\prime}$ tir. Köy sayısı 63 olup, toplam nüfus 13.717'dir. Bunların 7.027'si erkek, 6.384'ü kadın olmak üzere 13.411'i Müslüman; 164'ü erkek 142'si kadın olmak üzere 306'sı Rum'dur. Ayrıca Taşdibi ve Susuz Yayla mevkilerinde Antimon madenleri bulunmaktadır ve çıkarılması için gerekli imtiyazlar verilmiştir. (HVS, 1310: 426-427). 1305 Karesi Vilayet Salnamesinde ise bu nahiyenin çoğu köyünde halı, kilim ve seccade dokumacılığı yapıldığı bilgisi vardır (Mutaf, 1997: 172).

Giresun nahiyesinin çok özel bir öneminin olmadığını ayrıca vurgulayan Cuinet, nüfusunun 13'ü Rum Ortodoks olmak üzere toplam 4.606 kişi olduğunu belirtmiştir. Nahiyede 10 cami/mescit, 15 okul, 48 butik, 15 değirmen, 1 han veya otel bulunmaktadır. Nahiye merkezinde ise 2.912' si Müslüman, 88'i Rum Ortodoks olmak üzere toplam 3.000 kişi vardır. Burada, hükümet konağı, belediye binası, 1 posta idaresi, 1 orman idaresi, 1 tarım komisyonu vb. sayılmıştır. Nahiye 3.000 hektarını meşe ve çam ağaçlarının oluşturduğu güzel ormanla beraber toplam 19.000 hektarlık yüzölçümüne sahiptir. Geri kalanında Simav Çayı ve kollarının suladığı geniş ekili ovada tahıl, pamuk, her çeşit sebze ve meyve bakımından bol hasat yapılmaktadır. 1307 Hüdavendigar Salnamesinde de aynı bilgiler tekrarlanmakla beraber 1310 Hüdavendigar Vilayet Salnamesinde diğer bilgiler tutarlı olup nüfus bir miktar daha fazladır (HVS, 1307: 138; HVS, 1310: 428).

Su-sığırlı (Susurluk): Aslında Fırt nahiyesine bağlı bir kasaba olmasına rağmen Cuinet burayı ayrı bir başlıkta incelemeyi tercih etmiştir. Cuinet, Balıkesir ve Bandırma'nın ortasında kalan bu yerde, yolcu ve arabacıların gecelemeyi bir adet haline getirdiklerini ve bu yüzden 5 yeni han veya otelin yapıldığını, bu durumun harabeye dönen geniş iki kervansarayın restorasyonunu çabuklaştırdığını ifade etmiştir. Sultançayır köyünde çıkan bor madeni hakkında madenleri anlattığı kısımda detaylı bilgi veren Cuinet, burada borasit 
madeninin bulunmasından ve işletilmesinden sonra bölgenin çok önemli hale geldiğini ifade etmiştir. Burası hakkında 1307 Hüdavendigar Vilayet Salnamesinde herhangi bir bilgi yer almazken 1310 Hüdavendigar Vilayet Salnamesinde borasit madenlerinden detaylı bir şekilde bahsedilmiştir. Bu madenlerin imtiyaz sahibi Osmanlı Bankası eski müdürü Mösyö Foster olup, o ölünce İngiliz Lord Hinklon'a geçmiştir. Bunun haricinde Furt nahiyesinde dört adet daha borasit madeni bulunduğu bilgisi de yer almaktadır (HVS, 1307: 140; HVS, 1310: 431-432).

Fırt nahiyesinin tarım üretiminin de iyi olmakla birlikte Cuinet asıl zenginliğinin madenleri olduğunu vurgulamıştır. Fırt nahiyesi hakkında 1307 Hüdavendigar Vilayet Salnamesinde 28 köyü, 10.064 nüfusu olduğu belirtilmiştir. Bunun 9.896's1 Müslüman 168'i Rum'dur. Nahiyede toplam 15 cami, 12 mescit, 30 mektep, 31 değirmen, 45 dükkân 3.428 hane bulunmaktadir (HVS, 1307: 140).

Balat nahiyesi 175'i Rum Ortodoks olmak üzere toplam 9.375 kişilik bir kasabadır. Burada 5 minareli camii, 3 medrese, 1 kilise, 3 han veya otel, 1 hamam, 75 butik ve 675 hane sayılmıştır. Nahiye 39 köyden müteşekkil olup 1.958 hanelidir. Burada 11.340 kişi ve 18 okul tespit edilmiştir. 1307 Hüdavendigar Vilayet Salnamesi Cuinet'in nüfus hariç diğer verdiği bilgileri destekler mahiyettedir. Nüfus sayısı ise Rumlar yine 175 olmak üzere toplamda 9.540 olarak verilmiştir (HVS, 1307: 141).

Cuinet'in Balıkesir nahiyeleri hakkında verdiği bilgiler ile Osmanlı kayıtları karşılaştırıldığında çoğunun 1307 Hüdavendigar Vilayet Salnamesi ile aynı olduğu görülmektedir. Buradan Cuinet'in eserini hazırlarken Balıkesir hakkında elde ettiği bilgilerin büyük bir kısmının Osmanlı kayıtlarına dayandığını bunun yanında kendisinin de bölgede yaptığı incelemeleri ilave ettiğini söylemek mümkündür.

\section{Karesi Sancağının Gelirleri}

Uzun yıllar bütçe açıkları ile mücadele eden Osmanlı maliyesi, 1881 Muharrem Kararnamesi ile iflasını bildirdikten ve Duyun-ı Umumiye İdaresi kurulduktan sonraki süreçte gelirlerini artırmaya yönelik girişimlerde bulunmuştur. Bunlar arasında aşar vergisinin tahsilinde yaşanan sıkıntıların giderilerek bu kalemin artırılması, kaçakçılığı ortadan kaldıracak tedbirlerin alınması, gümrük ve zirai gelirlerin artırılması, sanayi ve ticareti geliştirmeye yönelik çalışmaların yapılması bulunmaktadır. Bunların hemen hepsinin birden gerçekleştirilmesi ve bütçeye yansıması zaman alacak olsa da mali prensiplerin oluşturulması bakımından mühim kararlardır. Bu çerçevede 1892 yılında Osmanlı genelinde daire ve vilayetlerden gelen verilere dayanılarak hazırlanan bütçe taslağında gelir 18.239.233 lira, gider ise 20.341.929 lira olarak öngörülmüştür. (Bölükbaşı, 2005: 66-77). Karesi Sancağının gelirlerine dair net olarak veri elde edilebilecek kaynaklar sınırlıdır. 1308 (1887) Karesi Vilayet Salnamesi bunlardan biri olsa da buradaki bilgilerden yola çıkılarak Karesi Sancağı gelirlerini tespit edebilmek mümkün değildir (Mutaf, 1997: 203). Çünkü bu dönemde vilayet olan Karesi'ye Biga Sancağ da dâhildir.

Cuinet alacaklı kurumun çalışanı olarak sancağın gelirlerini detaylı bir şekilde yazmıştır. Karesi Sancağının 1892 yılında gelirlerinin büyük bir kısmını tütünden alınan aşar vergisi, tuz, ispirtolu içki, posta pulu, ipek ve balıkçılıktan elde edilen gelirler oluşturmaktadır. Bunlar Osmanlı gelirleri arasında önemli yer tutan kalemlerdir. Giderlerini ise memurlara ödenen maaşlar ve diğer masraflar içermektedir. Vilayet toplam geliri 2.117.715 kuruş iken 
giderleri 372.670 kuruştur. Masraflar düşüldükten sonra kalan net gelir ise 1.745 .045 kuruştur (Cuinet, IV, 1894: 251). Vilayet gelirlerinin kalemlere ayrılmış hali ise aşağıdaki tabloda olduğu gibidir:

Tablo 2. Karesi Sancağının Gelirleri

\begin{tabular}{lc}
\hline Gelir Türü & Miktar (kuruş) \\
\hline Tütünlerin Aşar Vergisi & 107.815 \\
Tuz & 279.629 \\
İspirtolu İçki & 893.145 \\
Pul & 370.526 \\
İpek & 107.932 \\
Balıkçllık & 73.158 \\
Diğerleri (Yeni Gelirler) & 205.150 \\
Toplam & 2.117 .715 \\
\hline
\end{tabular}

\section{Nüfus}

Karesi Sancağı ve merkezi Balıkesir'in nüfusuna dair bilgi edinebileceğimiz çeşitli kaynaklar mevcuttur. Bunlardan birincisi elbette devlet tarafından özellikle vergi gelirlerinin tespiti amacıyla zaman zaman yapılan nüfus ve temettuat kayıtlarıdır. Balıkesir'e ait olan bu defteler 1840-1845 yıllarına aittir. (BOA, NFS.d., 1262; BOA, KK.d., 6479). Bir diğer kaynak ise vilayet salnameleridir. Cuinet'in eserini hazırladığı döneme en yakın kayıtlar ise 1881 yılında başlayan ve büyük bir kısmı 1889'da tamamlanarak 1893'te padişaha sunulan nüfus sayımlarıdır (Karpat, 2010: 105). Nüfus yoğunluğunu Türklerin oluşturduğu Karesi Sancağında Bandırma, Erdek ve Ayvalık gibi sancağın liman ticaretinin yoğun olduğu bölgelerde Ortodoks Rumlar çoğunluktadır. 1887 yıllarında sancağın toplam nüfusu 280.773 olarak verilmiştir. Bölgede nüfus artışı bu dönemde devam etmektedir (Mutaf, 1997: 23,163). Ancak muhtemelen bu toplam nüfusa kadınlar dâhil edilmemiştir. Cuinet, Karesi Sancağının toplam nüfusunu 389.730 olarak vermiştir Cuinet, IV, 252). Bu nüfusun dağılımı ise aşağıdaki tabloda olduğu gibidir:

Tablo 3. Karesi Sancağı Nüfusu

\begin{tabular}{lllllllll}
\hline Kazalar & Müslüman & $\begin{array}{l}\text { Ortodoks } \\
\text { Rum }\end{array}$ & Ermeni & Bulgar & Yahudi & Yabancı & Muhtelif & Toplam \\
& \multicolumn{1}{c}{} & & & & & & \\
\hline Balıkesir & 103.624 & 2.351 & 1.941 & 1.577 & - & - & 36 & 109.529 \\
& & & & & & & & \\
\hline
\end{tabular}


Vital Cuinet'e Göre XIX. Yüzyıl Sonlarında Balıkesir'in İdari, Demografik ve SosyoEkonomik Yapısı

\begin{tabular}{|c|c|c|c|c|c|c|c|c|}
\hline Ayvalık & 180 & 21.486 & - & - & - & 1.506 & - & 23.172 \\
\hline Kemer & 16.749 & 2.062 & - & - & - & - & - & 18.811 \\
\hline Edremit & 42.933 & 7.482 & - & - & - & - & 194 & 50.614 \\
\hline Erdek & 5.418 & 54.407 & 706 & - & 492 & 98 & 98 & 61.279 \\
\hline Gönen & 25.601 & 1.854 & 13 & 15 & 4 & - & - & 26.887 \\
\hline Bandırma & 50.594 & 5.914 & 5.860 & - & - & - & 1.120 & 63.448 \\
\hline Bigadiç & 12.771 & 34 & - & - & - & - & - & 12.805 \\
\hline Sindirg1 & 22.436 & 715 & - & - & & - & - & 23.145 \\
\hline Toplam & 279.700 & 96.365 & 8.520 & 1.592 & 501 & 1604 & 1.418 & 389.730 \\
\hline
\end{tabular}

1881/1882-1893 yılları arasını kapsayan dönemde yapılan ve kadınların da sayıldığı Osmanlı genel sayımında ise Karesi Sancağının toplam nüfusu 336.341'dir. (Karpat, 2010: 105, 280281). Aradaki farkın nedeni zamanla meydana gelen doğumlarla artan nüfus olarak açıklanamayacağından bu dönemde sürmekte olan göç hareketleri olabileceği düşünülebilir. 1878-1912 yılları arasında başta Bulgaristan olmak üzere Bosna-Hersek, Karadă̆, Sırbistan, Romanya, Yunanistan, Girit, Batum, Dağıstan, Kaşgar ve İran'dan Anadolu'ya göçmen toplulukları gördükleri baskılar sonucu gelmiştir. Bunların bir kısmı da Karesi Sancağına yerleştirilmiştir (Kodaman ve İpek, 2000: 387; Koç, 2014).

Tablo 4. 1881/1882-1893 Osmanlı Genel Sayımına Göre Karesi Sancağı Nüfusu

(Karpat, 2010: 280-281)

\begin{tabular}{|c|c|c|c|c|c|c|c|c|c|c|c|c|c|c|c|}
\hline \multirow[t]{2}{*}{ Kazalar } & \multicolumn{2}{|c|}{ Müslüman } & \multicolumn{2}{|l|}{ Rum } & \multicolumn{2}{|c|}{ Ermeni } & \multicolumn{2}{|c|}{ Bulgar } & \multicolumn{2}{|c|}{ Yahudi } & \multicolumn{2}{|c|}{ Yabanci } & \multicolumn{2}{|c|}{ Katolik } & \multirow[t]{2}{*}{ Toplam } \\
\hline & $\mathbf{K}$ & E & $\mathbf{K}$ & E & $\mathbf{K}$ & E & K & $E$ & $\mathbf{K}$ & E & $\mathbf{K}$ & E & $\mathbf{K}$ & $E$ & \\
\hline Balıkesir & 53.972 & 56.353 & 958 & 1.002 & 956 & 844 & 265 & 988 & & & 14 & 22 & & & 115.374 \\
\hline Ayvalık & 40 & 50 & 9.798 & 10.335 & & & & & & & 703 & 751 & & & 21.677 \\
\hline Kemer & 8.183 & 8.962 & 1.035 & 1.398 & 1 & 8 & & & & & 4 & 4 & & & 19.595 \\
\hline Edremit & 12.851 & 14.148 & 2.591 & 2.937 & 4 & 6 & & & 1 & 4 & 95 & 99 & & & 32.736 \\
\hline Erdek & 1.485 & 1.585 & 14.462 & 14.703 & 8 & 10 & & & 154 & 146 & 194 & 260 & & & 33.007 \\
\hline Gönen & 11.997 & 11.926 & 855 & 837 & 5 & 8 & & 5 & 3 & 6 & & & & & 25.642 \\
\hline Bandirma & 14.519 & 15.473 & 2.762 & 2.725 & 2.282 & 2.175 & & & & & 59 & 68 & 443 & 446 & 40.912 \\
\hline Bigadiç & 11.778 & 11.378 & 52 & 99 & & & & & & & & & & & 23.307 \\
\hline
\end{tabular}




\begin{tabular}{|c|c|c|c|c|c|c|c|c|c|c|c|c|c|c|c|}
\hline Sindirg1 & 11.650 & 11.604 & 400 & 437 & & & & & & & & & & & 24.091 \\
\hline Toplam & 126.475 & 131.479 & 32.913 & 34.473 & 3.256 & 3.051 & 265 & 993 & 158 & 156 & 1.069 & 1.204 & 443 & 446 & 336.341 \\
\hline
\end{tabular}

Balıkesir şehir merkezi de sancak genelinde olduğu gibi çoğunluğunu Müslümanların oluşturduğu bir yapıya sahiptir. Şehrin gayrimüslim sakinleri 17. yüzyıla kadar Ortodoks ve Yahudilerdir. Bu yüzyıldan itibaren Celali isyanlarının Anadolu'da yarattığı etkilerden kaçan bir kısım Ermeni de şehre yerleşmiştir. Zamanla Yahudiler şehirden göç etmişlerdir (Öntuğ, 2006:358). Böylece şehrin demografik yapısı Müslümanların yine çoğunlukta olduğu Ortodoks, Rum ve Ermenileri de içinde barındıran bir şekle bürünmüştür. Şehrin nüfusu ile ilgili yapılan çalışmalara bakıldığında 1831 nüfus sayımında şehirde 4.596 erkek tespit edilmiştir ve bunların 804'ü gayrimüslimdir. Kadınlar eklendiğinde bu rakam tahmini olarak 9162'ye çıkmaktadır. 1840-1841 yılında ise şehrin nüfusu gerilemiştir. Bu sayıma göre şehirde toplam 3.736 erkek vardır ve bunların 738'i gayrimüslimdir. Kadınlar eklendiğinde bu sayısı yine tahmini olarak 7.472 kişiye tekabül etmektedir (Yağcı ve Genç, 2013: 47). 1853-1856 Osmanlı-Rus ve 1877-1878 Osmanlı Rus Savaşı'ndan sonra Anadolu'ya Kafkaslar ve Balkanlardan gelen göçmenlerin bir kısmı Balıkesir'e yerleştirilmiştir. Hatta bunun için şehirde yeni bir mahalle dahi kurulmuştur (Şimşir, 2004: 150-151). Dolayısıyla şehirde bir miktar nüfus artışı yaşanmıştır. Bunu Cuinet'in verdiği rakamlarda da görmek mümkündür. Cuinet şehirde çoğunluğu Müslümanlardan oluşan 13.118 kişinin bulunduğunu belirtmektedir. (Cuinet, IV, 1894: 263):

Tablo 5. Balıkesir Nüfusu

\begin{tabular}{lc}
\hline Cemaatler & Nüfus \\
\hline Müslümanlar & 9.875 \\
Rum Ortodokslar & 1.266 \\
Gregoryen Ermeniler & 1.941 \\
Diğer & 36 \\
Toplam & $\mathbf{1 3 . 1 1 8}$ \\
\hline
\end{tabular}

Cuinet'in verdiği bilgi 1307 Hüdavendigar Vilayet Salnamesi ile birebir örtüşmektedir (Hüdavendigar Vilayet Salnamesi, 1307: 132). Cuinet'in verdiği rakamları karşılaştırabileceğimiz ve 1889 yılında basılmış olan Şemseddin Sâmî'nin Kâmûsu'l-A'lâm adlı eserinde Balıkesir şehrinin nüfusu ile alakalı olarak yuvarlak bir rakam verilmiştir. Şemseddin Sâmî’ye göre şehirde 20.000 kişi bulunmaktadır. Tüm Balıkesir kazasında ise 2.500'ü Rum, 1.200'ü Ermeni olmak üzere toplam 87.000 kişi vardır. (Şemseddin Sâmî, 2, 1306: 1219). 


\section{E. Eğitim}

Karesi Sancağında 25'i yüksek, normal veya özel olmak üzere toplam 376 okul mevcuttur; yine 20 tanesi ortaokul (rüştiye) veya hazırlık sınıfı ve 331 ilkokul (iptidai) veya hazırlık sınıfı şeklindedir. Bu okullara 9.102'si erkek, 671'i kı çocuk olmak üzere toplam 9.773 öğrenci devam etmektedir (Cuinet, IV, 1894: 253).

Tablo 6. Karesi Sancağında Bulunan Okullar ve Öğrenci Sayıları (Cuinet, IV, 1894: 254)

\begin{tabular}{|c|c|c|c|c|c|c|c|c|c|c|c|c|}
\hline \multirow[t]{2}{*}{ Kazalar } & \multirow{2}{*}{$\begin{array}{l}\begin{array}{l}\text { Yüksek } \\
\text { (İdadi) }\end{array} \\
\text { Okul }\end{array}$} & \multirow{2}{*}{$\begin{array}{l}\text { Okul } \\
\text { Öğrenci }\end{array}$} & \multicolumn{4}{|c|}{ Ortaokul (Rüşdiye) } & \multicolumn{4}{|c|}{ İlkokul (Sıbyan) } & \multicolumn{2}{|c|}{ Toplam } \\
\hline & & & Okul & & Öğrenci & & Okul & & Öğrenci & & Okul & Öğrenci \\
\hline & & Sayıs1 & & & Sayısı & & & & Sayısı & & & Sayısı \\
\hline & Erkek & Erkek & Erkek & Kiz & Erkek & Kiz & Erkek & Kiz & Erkek & Kiz & & \\
\hline Balıkesir & 14 & 110 & 3 & 1 & 135 & 20 & 99 & 2 & 1925 & 55 & 119 & 2245 \\
\hline Ayvalık & - & - & 2 & 1 & 85 & 40 & 19 & 2 & 800 & 180 & 24 & 1105 \\
\hline Kemer & 1 & 20 & 1 & 1 & 30 & 20 & 11 & 1 & 340 & 30 & 15 & 440 \\
\hline Edremit & 1 & 15 & 2 & 1 & 80 & 24 & 26 & 1 & 1330 & 42 & 31 & 1491 \\
\hline Erdek & 1 & 10 & 1 & - & 50 & - & 22 & 3 & 714 & 110 & 27 & 834 \\
\hline Gönen & 2 & 16 & 1 & - & 60 & - & 44 & 1 & 1045 & 25 & 48 & 1146 \\
\hline Bandırma & 2 & 25 & 3 & 2 & 135 & 37 & 45 & 3 & 903 & 88 & 55 & 1188 \\
\hline Bigadiç & 2 & 18 & - & - & - & - & 22 & - & 551 & - & 24 & 569 \\
\hline Sindirgi & 2 & 17 & 1 & - & 29 & - & 30 & - & 659 & - & 83 & 705 \\
\hline Toplam & 25 & 231 & 14 & 6 & 304 & 141 & 318 & 13 & 8.267 & 530 & 376 & 9.773 \\
\hline
\end{tabular}

Bu okulların cemaatlere göre ayrılmış şekli ise aşağıdaki tabloda olduğu gibidir (Cuinet, IV, 1894: 255):

Tablo 7. Karesi Sancağında Mevcut Okul ve Öğrencilerin Cemaatlere Göre Dağılımı

\begin{tabular}{llll}
\hline Cemaatler & Okullar & Öğrenci Sayısı & Toplam \\
\hline
\end{tabular}




\begin{tabular}{lcccccc}
\hline & Erkek & K1z & Erkek & Kiz & Okul & Öğrenci \\
Müslümanlar & 249 & - & 5.283 & - & 249 & 583 \\
Ortodoks Rumlar & 102 & 14 & 3.554 & 572 & 116 & 4126 \\
Gregoryen Ermeniler & 5 & 4 & 215 & 77 & 9 & 292 \\
Yahudiler (Musevi) & 1 & 1 & 50 & 22 & 2 & 72 \\
Toplam & 357 & $\mathbf{1 9}$ & $\mathbf{9 1 0 2}$ & $\mathbf{6 7 1}$ & $\mathbf{3 7 6}$ & $\mathbf{9 . 7 7 3}$ \\
\hline
\end{tabular}

Balıkesir merkez kazasında ise toplam 119 okulda 2.245 öğrenci olmak üzere bunların cemaatlere dağılımı aşağıda olduğu gibidir (Cuinet, IV, 1894: 264):

$\begin{array}{lll}\text { Müslümanlar: } & 14 \text { medrese ve bir sivil yüksekokulda } & 110 \text { öğrenci } \\ & 2 \text { lise } & 85 \\ & 90 \text { ilkokul erkek } & 1.550 \\ \text { Rum Ortodoks: } & 1 \text { lise veya erkek ortaöğretim (Jimnazyum) } & 50 \\ & 1 \text { pansiyon genç kılar için } & 20 \\ & 8 \text { ilkokul erkek } & 315 \\ & 1 \text { ilkokul kız } & 30 \\ \text { Gregoryen Ermeni: } & 1 \text { ilkokul erkek } & 60 \\ & 1 \text { ilkokul kız } & 25 \\ \text { Toplam: } & 19 \text { okul } & 2.245 \text { öğrenci }\end{array}$

Cuinet'in yüksekokul olarak saydığı 25 okul 1310 Hüdavendigar Vilayet Salnamesinde bulunmamaktadır. Cuinet'in belirttiği yüksekokulların özel ve gayrimüslim okulları olduğu düşünülebilir. Bunun yanı sıra vilayet salnamesinde okul ve öğrenci sayılarının daha fazla olduğu görülmektedir. Salnameye göre 1894-1895 yılında okul ve öğrenci sayıları aşağıdaki gibidir (HVS, 1310: 470-477):

Tablo 8. 1310 Hüdavendigar Salnamesinde Karesi Sancağında Eğitim

\begin{tabular}{|c|c|c|c|c|c|}
\hline \multirow[t]{2}{*}{ Kazalar } & \multicolumn{2}{|c|}{ Ortaokul (Rüşdiye) } & \multicolumn{2}{|c|}{ İlkokul (Sıbyan) } & \multirow[t]{2}{*}{ Toplam } \\
\hline & Okul & $\begin{array}{l}\text { Ö̈̆renci } \\
\text { Sayısı }\end{array}$ & Okul & $\begin{array}{l}\text { Ö̈̆renci } \\
\text { Sayısı }\end{array}$ & \\
\hline
\end{tabular}


Vital Cuinet'e Göre XIX. Yüzyıl Sonlarında Balıkesir'in İdari, Demografik ve SosyoEkonomik Yapısı

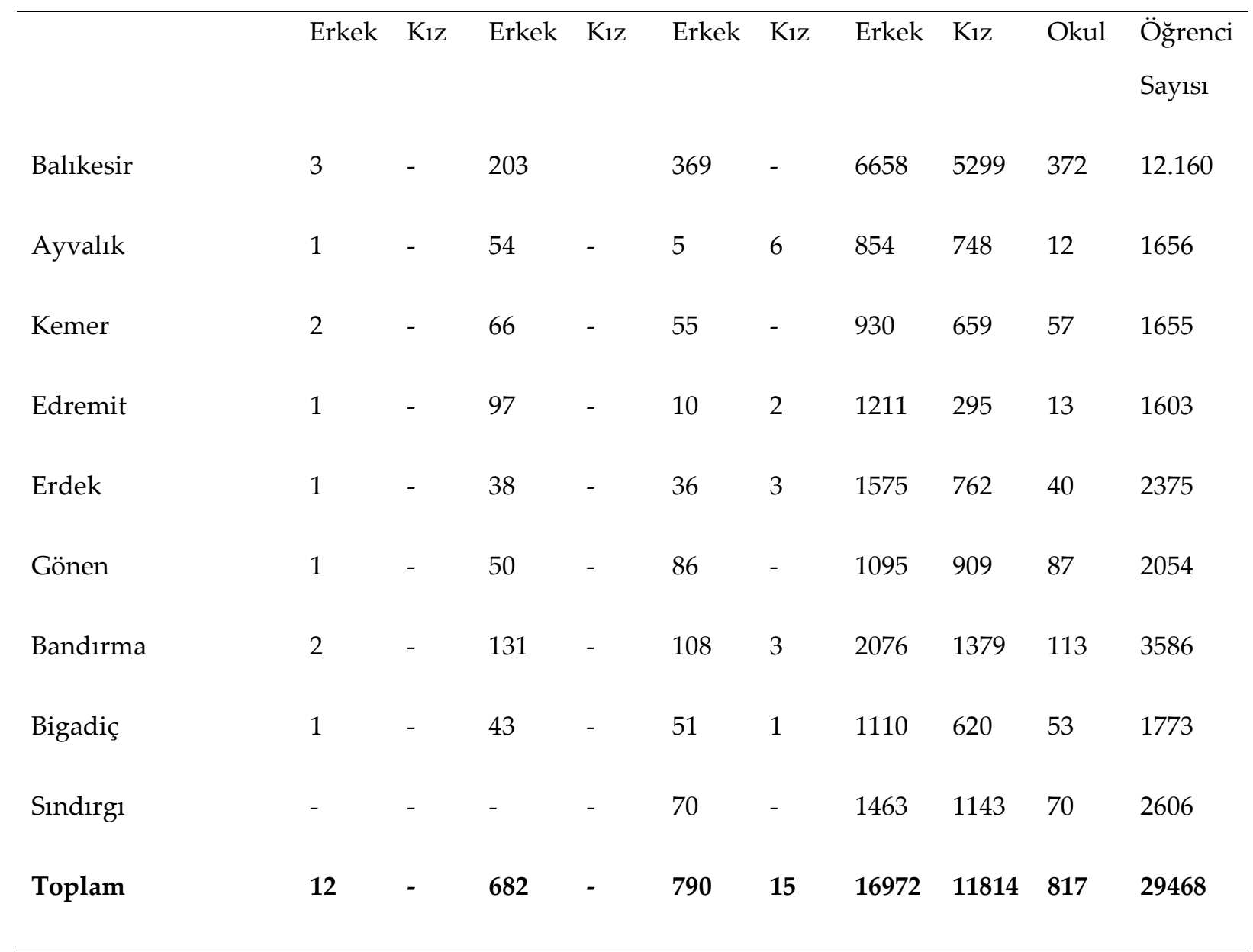

\section{F. Tarım}

Eskiden beri özellikle İstanbul'un iaşesinde önemli rol oynayan Balıkesir ve çevresinin önemi XIX. yüzyıla gelindiğinde artarak devam etmiştir (Çelik, 2012: 77-78) Balıkesir merkez ve bağlı köylerde elde edilen ürünler buğday, arpa, susam, afyon, nohut, bakla ve iyi otsamandır. Aynı zamanda endüstri olarak tütün üreticiliği de önemli bir yer tutmaktadır. İvrindi, Fırt, Balya ve Kepsut'ta üretilen tütünler en kaliteli olanlardır. Cuinet, Sancağın tamamında $1.500 .000 \mathrm{~kg}$. civarında kaliteli tütün yaprağı üretiminin gerçekleşmesinin beklendiğini kaydetmiştir (Cuinet, IV: 258). Balıkesir'de her çeşit sebze ve lezzetli meyveler yetiştirilmektedir. Hatta Hasan Bey adı verilen çok kıymetli ve diğerlerinden üstün nefis bir kavun vardır. Bu kavun Balıkesir civarında yetiştirilip İstanbul'a gönderilir. Cuinet, Balıkesir' de yetişen bamyaya ayrıca vurgu yapmıştır. Balıkesir ve civarında tadı hoş, iriliğine rağmen çok aranan bamya yetiştiğini ve bizim bildiğimiz tabirle de genellikle en küçük bamyalara değer verildiğini ifade etmiştir. Arıcılığın bölgede yaygın olarak yapıldığını ve Balıkesir balının da çok meşhur olduğunu belirtmiştir (Cuinet, IV: 265). Karesi Sancağında yıllık ortalama 2.248.205 hektolitre (100 lt buğdayın $\mathrm{kg}$ cinsinden ifadesi) tahıl ve 79.068.205 kilogram çeşitli ürünler üretilmektedir (Cuinet, IV: 255-256). Bunların dağılımı ise aşağıdaki tabloda olduğu gibidir:

Tablo 9. Karesi Sancağında Üretilen Tarım Ürünleri ve Miktarı 


\begin{tabular}{lc}
\hline Ürün & Hektolitre \\
\hline Buğday & 892.600 \\
Arpa & 770.494 \\
Çavdar & 140.163 \\
Yulaf & 165.158 \\
Buğday yulaf karışımı (meteil) & 49.212 \\
Misır & 110.829 \\
Darı (millet) & 89.886 \\
Diğerleri & $\mathbf{1 2 9 . 1 5 3}$ \\
\hline
\end{tabular}

\begin{tabular}{|c|c|c|c|c|c|}
\hline Ürün & Kilogram & Ürün & Kilogram & Ürün & Kilogram \\
\hline Fasulye & 4.201 .040 & Tütün & 1.500 .000 & $\begin{array}{l}\text { Diğer } \\
\text { meyveler }\end{array}$ & 30.000 .000 \\
\hline Yeşil fasulye & 475.361 & Zeytinyağı & 8.102 .000 & $\begin{array}{l}\text { Tepelik } \\
\text { (vallonée) }\end{array}$ & 3.500 .000 \\
\hline Nohut & 2.112 .660 & Şarap & 7.600 .000 & Kestane & 456.000 \\
\hline Mercimek & 81.310 & Kenevir & 10.070 & Ceviz & 513.120 \\
\hline Burçak & 103.006 & Bal & 102.636 & $\begin{array}{l}\text { İpek } \\
\text { kozası }\end{array}$ & 112.692 \\
\hline Keten Tohumu & 87.622 & Balmumu & 9.107 & İpek & 29.450 \\
\hline Susam & 145.252 & İncir & 614.000 & Keçi Yünü & 125.000 \\
\hline Pamuk & 456.062 & $\begin{array}{l}\text { Taze } \\
\text { üzüm }\end{array}$ & 15.600 .000 & Tiftik yün & 153.954 \\
\hline
\end{tabular}


Vital Cuinet'e Göre XIX. Yüzyıl Sonlarında Balıkesir'in İdari, Demografik ve SosyoEkonomik Yapıs1

\begin{tabular}{llllll}
\hline Afyon & 225.659 & Rakı & 397.000 & Yün & 180.660 \\
Diğerleri & 250.175 & & & & \\
& & & & & \\
\end{tabular}

İklimi ve arazisi müsait olan Karesi'de sebze, yaş ve kuru meyve üreticiliğinde çeşitlilik bol olmakla birlikte bunların içerisinde üzüm ayrı bir yer tutmaktadır. Zira buradaki üzümden elde edilen şarap çok kalitelidir ve Avrupa'ya ihraç edilmektedir. Cuinet, İstanbul Fransız Ticaret Odasının aylık bülteninden aldığ 1892'nin bir yıllık Bandırma bölgesinde üretilen üzüm, şarap ve rakı verilerini aktarmıştır. En iyi şarabın Avşa'nın olduğunu, mavnaların İstanbul'a gittiğini, orada Marmara şaraplarını Avşa ve Paşa Limanı şarapları adı altında sattıklarını anlatmıştır. Özellikle Paşa Limanı'ndan Erdek, Hereke ve Alonya'dan olduğu gibi üretilen bütün şarapların Avrupa'ya ihraç edildiğini, bunların 13 ila 15 derece olup 10 okkası (12 kg 820 gr) 6 ve 10 hatta 12 kuruşa satıldığını ifade etmiştir. Bir Türk Lirasının 108 kuruş olduğunu da ayrıca belirtmiştir. Üzüm ezme makinasının ise yeteri kadar olmadığı, bütün bölgede sadece 2 ya da 3 tane olduğu bilgisini de vermiştir (Cuinet, 1894: 256).

Tablo 10. 1892 Yılında Balıkesir Bandırma Bölgesinde Elde Edilen Üzüm, Şarap ve Rakı Miktarı (Kilogram)

\begin{tabular}{lcccc}
\hline Yer Adı & Üretici & Üzüm & Şarap & Raki \\
& Sayısı & & & \\
\hline Erdek & 390 & 5.610 .000 & 3.234 .000 & 154.000 \\
Hereke & 95 & 1.645 .000 & 495.000 & 22.000 \\
Edincik & 99 & 110.000 & 88.000 & 2.200 \\
Kara Biga & 40 & 55.000 & 16.500 & 1.800 \\
Paşa Limanı & 130 & 1.540 .000 & 660.000 & 33.000 \\
Avşa & 80 & 1.150 .000 & 775.500 & 44.000 \\
Ekinlik & 130 & 1.650 .000 & 990.000 & 7.000 \\
Balıklı (Gr. Skoupia) & 101 & 418.000 & 198.000 & 14.000 \\
Alonya & 82 & 139.000 & 57.200 & 27.500 \\
Marmara & 170 & 1.078 .000 & 539.000 & 26.500 \\
\hline & & & & \\
\hline
\end{tabular}




\begin{tabular}{lcccc}
\hline Kalemi & 102 & 605.000 & 275.000 & 16.500 \\
Bandırma ve bağlı üç köyü & 180 & 440.000 & 121.000 & 13.000 \\
Gönen & 55 & 132.000 & 44.000 & 2.000 \\
Perama & 150 & 462.000 & 240.000 & 13.000 \\
Monhania (Munhani?) & 21 & 50.000 & 18.700 & 700 \\
Prastros & 125 & 560.000 & 253.000 & 16.000 \\
Mihaliç & 56 & 110.000 & 30.000 & 12.000
\end{tabular}

Yukarıdaki tabloda da görüldüğü gibi Balıkesir'de üzüm, şarap ve rakı üretiminde birinci sırada Erdek vardır. İdari bakımdan Erdek'e bağlı küçük bir ada olan Ekinlik'in yüzölçümü ve nüfusunun azlığına rağmen üzüm ve şarap üretiminde ikinci sırayı alması da bölge halkının geçimini buradan sağladığının bir göstergesidir.

\section{G. Hayvancilık}

Karesi'de hayvancılık daha çok küçükbaş hayvancılığa dayanmaktadır. Koşu ve sağma hayvanı olarak yetiştirilen karasığırların küçük ve sütünün ve az olması bu alanda besiciliğin sınırlı olmasında etkendir. Camus ve manda da bölgede beslenen diğer büyük başlardır (Mutaf, 1997: 30). Cuinet'in sancakta 1892 yılı besiciliğine dair verdiği rakamlar ise aşağıda olduğu gibidir (Cuinet, IV, 1894: 259):

Tablo 11. Balıkesir'de Hayvanların Cinsi ve Sayısı

\begin{tabular}{lc}
\hline \multicolumn{1}{c}{ Hayvanın Cinsi } & Baş Sayısı \\
\hline Sığır/İnek & 200.000 \\
At ve katır & 35.000 \\
Koyun & 244.000 \\
Keçi (her ikisi ortak) & 123.000 \\
Keçi tiftik & 182.300 \\
Deve & 3.000 \\
Toplam & 788.000 \\
\hline
\end{tabular}


Cuinet, bazı Rum köylerinde domuz beslendiğini, en bakımlı sürü hayvanlarının moher yani tiftik keçileri olduğunu belirtmektedir. Koyunların sütünden yapılan peynirin bölgede tüketildiğini, tiftik keçisinden moherin, koyunlardan elde edilen yünün Bandırma ve Akçay'ın önemli ihracat ürünleri olduğunu ifade etmiştir. Ayrıca Balıkesir'in kaymağı gibi ihraç edilen tereyağının da İstanbul'da çok beğenildiğini, Türkiye ve Yunanistan'da özel olarak üretilen bir çeşit kaynamış sütten yapılan krem şeklindeki kaymağın haklı olarak çok lezzetli olduğunu ve içi boş rulo biçiminde hazırlanarak satışa sunulduğunu da ayrıca kaydetmiştir (Cuinet, IV, 1894: 259).

\section{H. Endüstri ve Ticaret}

Karesi Sancağı konumu itibarıla hem iç hem de dış ticaret konusunda oldukça iyi durumdadır. Kendi kendine yetebildiği gibi buradan komşu bölgelere çeşitli ticari mallar gönderilmektedir. Karesi Sancağının ithal ettiği ürünler, şeker, kahve, Amerikan bezi, çeşitli makinelerdir. (Mutaf, 1997: 53).

Karesi Sancağında belli başlı endüstri dalları sepicilik*, dericilik, sabunculuk, yağcılık, şarap ve iplik üretimi, pamuklu, ipekli, yünlü kumaş, halı dokumacılığı ve diğer tekstil ürünleri, un fabrikası, kerestecilik, tarım, orman ve madenciliktir. Bütün bunlar yetersiz ulaşıma rağmen önemli ihracat hareketliliği meydana getirmektedir. Balıkesir'in ithalat ve ihracat faaliyetleri ikisi Ege Denizi'ne (Ayvalık ve Akçay), üçü Erdek, Kapıdağ ve Bandırma körfezlerine olmak üzere toplam beş kapıdan yapılmaktadır.

Bu hareketliliğin yıllık ortalaması şöyledir (Cuinet, IV, 1894: 261):

İhracat: 34.074 .701 frank

İthalat: 8.511 .928 frank

Toplam: 42.586 .629 frank'tır.

Bu her kapının iştirak oranları ise aşağıdaki tabloda olduğu gibidir:

Tablo 12. Karesi Sancağı İthalat ve İhracat Miktarları

\begin{tabular}{lllc}
\hline Konum & $\begin{array}{l}\text { Toplam İthalat ve İhracat } \\
\text { (Frank) }\end{array}$ & İhracat (Frank) & İthalat(Frank) \\
\hline Ayvalık & 12.420 .724 & 9.024 .034 & 3.396 .690 \\
Akçay & 9.767 .356 & 7.967 .000 & 1.800 .355 \\
Erdek ve Kapıdağ & 2.761 .941 & 2.176 .210 & 585.731 \\
Bandırma & 17.636 .608 & 14.907 .456 & 2.729 .152 \\
\hline
\end{tabular}

\footnotetext{
* Hayvan derilerini kullanılacak hale getirmek için yapılan işlemler.
} 
Şemseddin Sâmî eserinin Karesi Sancağını anlattığı bölümde ihraç olunan ürünlerin yüklü miktarda şarap, zeytinyağı, kuru üzüm, rakı, palamut, ipek kozası, balmumu olduğunu, yalnız Bandırma ve Erdek limanlarından yıllık 15 milyon kilogramı aşkın üzüm, 8 milyon kilogram şarap ve 4 milyon kilogram rakı ihracatı yapıldığını belirtmiştir (Şemseddin Sâmî, 5, 1896: 3632). Bu da Cuinet'in verdiği bilgileri destekler niteliktedir ve bölgenin ihracat potansiyelini ortaya koyması bakımından mühimdir.

\section{Ulaşım}

Karesi Sancağı, Bursa'dan İzmir'e giden yol üzerinde olması, ayrıca liman bağlantısının bulunması bakımından önemli bir mevkidedir. Bu yol Kirmastı kasabasını ve Susurluk nehrini geçerek Balıkesir şehrine, oradan Bergama, Manisa, Menemen kasabalarına uğrar. Balıkesir şehrinden Bandırma'ya, Biga, Bayramiç kasabalarına uğrayarak Kala-i Sultaniye'ye ve Edremit'e giden yollar da vardır (Tevfik, 1308: 112). Buna rağmen Karesi Sancağında Bandırma'dan Balıkesir'e ve oradan da Edremit Körfezine giden tek bir araba yolu vardır. Bu yolun uzunluğu $175 \mathrm{~km}$ olup sancak merkezinden Marmara ve Ege denizinde Erdek ve Edremit körfezine ulaşılmaktadır. Bununla birlikte düzenli ulaşım şirketi yoktur. BalıkesirBandırma arasında fiyatlar ton başına ve kilosuna göre 40 ila 57 kuruş arasında değişmektedir. Hatta araba yüküne 34 kuruş, Manyas Gölü'nün su baskınlarıyla bozulan yolların tamir parası olarak hayvan başına 17 kuruş alınmaktadır. Balıkesir'den Edremit'e gidiş ücreti ton ve kilo başına göre 30 ile 40 kuruş arasında değişmektedir (Cuinet, IV, 1894: 260).

\section{J. Posta ve Telgraf}

Karesi Sancağının İstanbul ile olan posta bağlantısı buradan gelip-giden gemilerle yapılmaktadır. 1875 yılında Karesi posta işleri İdare-i Aziziye Şirketi Vapurları ile iki hat (iki hat üzerinden mi denilmek isteniyor, öyle ise: -iki hat üzerinden yürütülmeye başlanmıştır.Şeklinde cümle düzeltilebilir) olarak yürütülmeye başlamıştır. Telgraf ve Posta Nezaretinin kurulmasından sonra da bölgede teşkilatlanma yapılmıştır (Mutaf, 1997: 52). Cuinet bölgedeki telgraf istasyonları hakkında bilgi vermiştir. Buna göre bu sancakta 4 telgraf istasyonu vardır. Birincisi Bandırma'da uluslararası dille (Türkçe ve Fransızca) hizmet vermekte iken, diğer üçü Balıkesir, Erdek ve Bigadiç'te Türkçe (içeriye) hizmet vermektedir. $\mathrm{Bu}$ üç (iletişim dili muhakkak Türkçe) telgraf istasyonu aynı zamanda Karesi Sancağında Ayvalık, Kemer-Edremit ve Edremit'te kuruludur ve 13 mil deniz altından kablolarla Ayvalık'tan Midilli adasına, İzmir posta ve telgraf yönetimine de bağlıdır (Cuinet, IV, 1894: 252).

\section{K. Askeriye ve Polis Teşkilatı}

\section{a. Askeri Teşkilat}

Osmanlı Devleti'nde Tanzimat'tan sonraki süreçte devletin güvenliği, Hassa, Anadolu, Rumeli, Arabistan Ordusu gibi isimleri taşıyan ordular tarafından sağlanmaktadır. I. Meşrutiyet'ten sonra ise bu ordular birinci, ikinci ordu şeklinde sıralanmıştır. Karesi Sancağ askerî açıdan merkezi İstanbul'da olan Hassa Ordusu'nun güvenlik sınırları içerisindedir. Bu 
ordunun Ayvalık'ta bir kolu bulunmaktadır. 1847 yılında Balıkesir'de ise bir redif (ihtiyat askeri) taburu bulunmaktadır. Karesi Sancağı 1881-1888 yılları arasında müstakil vilayet haline getirilmiş ve bu süreçte askeri teşkilat da yeniden yapılandırılmıştır. Redif ve zaptiye şeklinde iki çeşit asker bulunmaktadır. Vilayetin genel asayiş ve güvenliğinden sorumlu olan Vilayet zaptiye alayı, komutanı olan alaybeyi tarafından komuta edilmektedir. Zaptiye alayının ise Balıkesir merkezi ile beraber, Edremit, Kemer, Ayvalık, Sındırgı, Bandırma, Erdek ve Gönen'de de birlikleri bulunmaktadır. Daha sonraları zaptiye askerinin yerini jandarma almıştır (Mutaf, 1997: 40).

Cuinet, Karesi Sancağındaki askeri birlikleri sayıları ile birlikte detaylı bir şekilde vermiştir. Buna göre Ayvalık'ta bir emir subayı ile teğmenin kumanda ettiği bir müfreze hariç Karesi Sancağında aktif nizami askerî bir birlik bulunmamaktadır. 6 tabur komuta heyetinin ve üç tabur, üç bölük mukaddem (öncü); üç tabur, üç redif bölüğü de tali (ihtiyat) olmak üzere 6 redif birliğinin görev yerleri aşağıdaki gibidir (Cuinet, IV, 1894: 250):

Balıkesir'de: Sancak merkezinde birisi öncü diğeri ihtiyat olmak üzere 2 tabur. Tabur komutanın emrinde görev alan 415 zaptiyeden müteşekkil bir müfreze görev yapmaktadır.

a. Edremit'te: Kaza merkezinde birisi öncü diğeri ihtiyat olmak üzere 2 tabur.

b. Bandırma' da: Kaza merkezinde birisi öncü diğeri ihtiyat olmak üzere 2 tabur.

c. Kepsut'ta: Birisi öncü diğeri ihtiyat olmak üzere 2 bölük.

d. Kemer-Edremit’te: Kaza merkezinde birisi öncü diğeri ihtiyat olmak üzere 2 bölük.

e. Gönen'de: Birisi öncü diğeri ihtiyat olmak üzere 2 bölük bulunmaktadır.

\section{b. Polis Teşkilatı}

Osmanlı Devleti'nde ilk defa 1261 (1845) yılında İstanbul'da kurulan Polis örgütü 18 Safer 1262 (16 Şubat 1846) tarihli irade-i seniye ile Zabtiye Müşirliği kurulduğunda kaldırılmış ve tüm kolluk örgülü bu Müşirliğe devredilmiştir (Gülmez, 1893: 1). 1881'de İstanbul Polis Teşkilatı yeniden kurulmuştur. 1894 yılına gelindiğinde Polis Teşkilatı on beş vilayette örgütlenmiştir (Akkaya, 2013: 63). Bunların arasında Balıkesir de vardır. Balıkesir'de polis teşkilatına ilk olarak 1887 yılında rastlanılmaktadır. Bu yılda vilayet olan Balıkesir merkezinde 2 komiser ve 7 polis görev yapmaktadır. Ayvalık'ta 1 komiser, 2 polis, Erdek'te 1 komiser, 2 polis, Bandırma'da 1 polis bulunmaktadır (Mutaf, 1997: 41).

Cuinet, Balıkesir kamu güvenliğine dair verdiği bilgide Balıkesir'de üçüncü sınıf bir komiser, 4 polis ve bir tabur komutanının kumandasında bulunan 223 piyade eri, 161 süvariden müteşekkil bir zaptiye topluluğu bulunduğunu, diğer kaza merkezlerinde hatta nahiyelerde ihtiyaca göre taksim edilen zaptiye ve polis örgütü bulunduğunu belirtmiştir (Cuinet, IV, 1894: 250-251).

\section{Ormanlar}

Osmanlı Devleti'nde ormancılığın tarihi çok geriye gitmemektedir. Devletin ormancılık politikası, daha çok memleket ahalisinin odun ihtiyacını karşılamaya yönelik olup bir iktisadi bilim ve çevre bilincinden yoksundur. Devlet tarafından tersanenin ihtiyacı haricindeki ormanları koruduğunu söylemek pek mümkün gözükmemektedir. Osmanlı 
Devleti orman davasının halli için iki yol izlemiştir. Bunlardan ilki köylüye baltalık vermek, diğeri devlet ormanlarından ücretsiz faydalanma imkânı tanımaktır. Tanzimat'la birlikte ormancılık alanında bir takım ilerlemeler kaydedilmiştir. Ormancılığın ekonomik boyutu kavranmış ve Ticaret Nezareti'ne bağlı Orman Müdürlüğü kurulmuştur (Güloğlu, 2010: 191192). Ormanların korunmasından çok gelir elde etmeye yönelik düzenlemelerin yapıldığ1 süreçte ormanlarla ilgili ilk düzenleme Fransız orman mühendislerinin öncülüğünde 1870 yılında yapılmıştır. Bu düzenlemede de ormanlar kamu ve mülk olarak sınıflandırılmıştır. Kamuya ait olan ormanlar devletin ihtiyaç duyduğu kereste vb. ihtiyaçlarının giderilmesi veya gelir elde etmek maksadıyla işletilmiştir. Ormanların işletme hakkını elde eden kişi veya şirket, ticarî amacı doğrultusunda kereste, odun vb. çıkararak bunların satışını gerçekleştirmiştir (Koç, 2005: 231-257).

Karesi Sancağında mevcut ormanlık alanın miktarı sancağın sınırı değiştikçe yıllar içerisinde farklılık gösterse de genel olarak sancak 300.000-400.000 hektar ormanlık alana sahiptir (Mutaf, 1997: 15). Cuinet'in verdiği bilgilere göre bu ormanların bir kismının devlet tarafından işletildiği anlaşılmaktadır. Buna göre Karesi Sancağında devlet gözetiminde işletilen ormanlar; 6 tanesi merkez kaza Balıkesir ve bir tanesi de Bigadiç'te olmak üzere toplam 7 tanedir. Toplam alanları $3.337 \mathrm{~km}^{2}$ olup genellikle meşe, gürgen, çam, köknar ağaçlarıyla kaplıdır. Bu ormanlar bölgenin ihtiyaçlarına göre işletilmekte, kereste yapımı, bazen toz/talaş veya tahta olarak kullanıldığı gibi, aynı zamanda çok sayıda fıçı tahtası ve imparatorluğun deniz kuvvetleri için kavisli tahtalar yapılmaktadır(Cuinet, IV, 1892: 257258). Devlet bu ormanların korunması hususunda oldukça hassastır. Arşivde bulunan ormanlarla ilgili vesikalar gelir getiren bu ormanların korunmasına yöneliktir. Örneğin hazine tarafından istifade edilmekte olan ve tersanenin ihtiyaç duyduğu kerestenin imal edildiği Yarışalanı ve Sularya ormanlık alanlarına 1891 yılında muhacirlerin yerleştirilmesi ve ormanları tahrip etmeleri üzerine bu göçmenleri yerleştiren Defter-i Hakani memuru Hıfzı Efendi görevinden alınarak cezalandırılmıştır. Muhacirlerin de buradan alınarak başka bir yere yerleştirilmeleri ya da ormanı tahrip etmemek şartıyla yerlerinde bırakılmaları kararlaştırılmıştır (BOA, DH.KMT., 1824/20 21 Şaban 1308, 1 Nisan 1891; BOA, DH.MKT., 1804/36, 18 Cemaziyelahir 1308, 29 Ocak 1891). Devlet gözetiminde işletilen ormanlardan

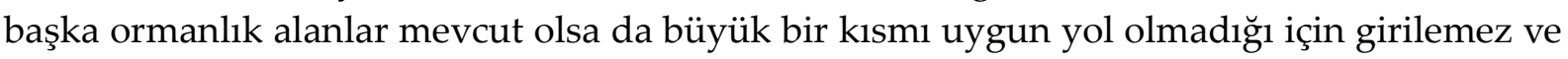
düzenli bir şekilde işletilemez durumdadır. Zira Edremit, Gönen, Bandırma Sındırgı ve Erdek kazalarının ki gibi dağlıktır. Buraların tam yüzölçümü bilinmemekle beraber daha çok ağaç çeşidi bulunmaktadır. Bütün genç ağaçların filizleri yeni sürgünleri, kışın kurumuş yaprakları ve önceki yılın tomurcukları bunlarla beslenen keçiler için kullanılmaktadır. Orman çamları kışın ısınmak için tercih edilmektedir. Çınar, söğüt, kavak, ağaçlarından kaşıklar oyulur, kızılağaç, ıhlamur ağacından tahtadan avadanlıklar yapılır. Ormanlardaki çok sayıda kömürcü gürgen, dişbudak ve ceviz dallarını tercih ederler. Bulgarlar tarafından kurulan ve işletilen Balıkesir ve Gönen kazalarındaki hızar tesisleri tamamen ilkel metotlarla işlemektedir. Bu tesisler yaklaşık 30 kadardır. Bandırma kazasının ormanına bağlı kurulan bir mekanik hızar fabrikası da bulunmaktadır. Balıkesir merkez kazasına bağlı Balya nahiyesindeki yaklaşık 5.000 hektar ile Kepsut nahiyesinde bulunan 3.000 hektarlık ormanda dikkate değer üretim yapılmaktadır. Karesi Sancağının ormanlarından elde edilen başlıca hasat (rekolte) arasında sepicilik (deri işlemecilik) amaciyla toplanan meşe, çam ve köknar ağaçlarının kabuklarını zikretmek gerekir. Kestane, fındık ve gürgen/kayın kozalağından yenebilir bir yağ elde edilmektedir, yine çok aranan çam fıstığ pinus, pinea, mazı, katran, zift, sumak, jalap (bitki reçinesi), bir çeşit yosun vb. yapılmaktadır (Cuinet, IV, 1892: 257- 
258). Şemseddin Sâmî'nin eserinde Cuinet'in verdiği bu bilgiler tekrarlanmış ve Balıkesir kazasında biri 5.000 diğeri 3.000 yeni dönüm ormandan külliyetli miktarda palamut elde ettiği belirtilmiştir (Şemseddin Sâmî, 1896: 3632). 1305 Karesi Vilayet Salnamesinde Karesi Sancağı ormanlık alanları, ağaç çeşitleri ve nerelerde kullanıldığı gibi detaylı bilgiler mevcuttur (Mutaf, 1997, s. 165-168). Cuinet'in verdiği bilgilerdeki en özgün olan kısım ise bölgede bulunan hızar makinelerinin çeşit ve sayıları ile ilgili olan bölümdür. Cuinet bu bilgileri muhtemelen bölgeyi ziyaretinde bizzat görerek yazmıştır.

İlave olarak Cuinet bütün bu ormanlarda çok sayıda vahşi hayvan barındığını belirtmiştir. Bölgede tespit edilebilen başlıca yaban hayvanları ayı, küçük bir leopar türü, kurt, tilki, yaban domuzu, vaşak, çakal, sırtlan, porsuk, su samuru, ağaç sansarı, vahşi kedi, birkaç tane alageyik, geyik, karaca, çok sayıda tavşan, çeşitli türden tüylü av kuşları (sülün, çulluk, toykuşu, hindi, kuğu, vahşi kazlar, çok sayıda ördek, güvercin, keklik, bıldırcın, ardıçkuşu, karatavuk, su çulluğu, ve başka av kuşları sürüsüdür (Cuinet, IV, 1894: 258).

\section{Madenler}

Cuinet, Balıkesir bölgesinde çıkarılan madenleri Simli gümüş, borasit, antimon ve bitümlü kömür olarak sıralamıştır Cuinet'e göre Hoca Gümüş madeninde yıllık \%40 ila \%50 oranında kurşun ve ton başına 1.800 ila 2500 gram gümüşi içeren değeri 12 ila 15 Türk Lirası ya da 276 ila 345 frank olan yıllık 4.000 ton simli gümüş cevheri üretilmektedir. Madende 400 işçi çalışmaktadır. Madenin çıkarılması, su iletimi ve cevherin hazırlanması için 6 makine kullanılmaktadır. Sonunculardan biri 135 beygir gücüne sahip ve ortalama gümüş verimini $\% 45$ yerine $\% 75$ 'e çıkarmaktadır. Son zamanlarda çeşitli galeriler telefonla iletişim kurmakta ve dolaşım raylar üzerinde yapılmaktadır. Hoca Gümüş madenini Edremit'teki Balıkesir yoluna bağlayan yeni bir yol inşa edilmiştir. Maden şirketi hükümete maden satışından elde edilen gelirden \%10'luk bir pay ödemektedir Aynı merkez İvrindi-Balıkçıpazarı nahiyesinde bir antimon madeni, 5 yıl boyunca İstanbul'daki Lorando Şirketi tarafından çıkarılmıştır (Cuinet, IV, 1894: 257).

Cuinet'in Balıkesir madenlerine dair verdiği bilgiler içerisinde en can alıcısı bor madeninin bölgede bulunuşuna dairdir. Borasit madenleri Karesi Sancağı merkeze bağlı Sultan Çayır ve Fırt nahiyesinde bulunmaktadır. Bu önemli madenlerin ilk imtiyazı Sultan Abdülmecit'in yaptığı kanun ve düzenlemelerden sonra Asya Türkiyesi'nde yabancılara verilen en eski imtiyazlardandır.

Cuinet, bor madeninin Balıkesir'de tesadüfen bulunduğunu anlatmıştır. Bor madeninin bulunması aslında bir nevi Mişel Paşa'nın Osmanlı ülkesinde deniz fenerleri inşa etmek üzere Fenerler İdaresi müdürü olması, onun da deniz fenerleri inşası için Desmazures ve Groppler'i 1856 yılında Osmanlı ülkesine getirmesi ile başlar. Bu kişiler Osmanlı Devleti'nde deniz fenerleri inşa etmişlerdir. Groppler ve Desmazures sonradan bölgede mermer ocağ işletmesinde birlikte çalışmaya başlarlar. Groppler'ın işletmesinde mermerin kesildikten sonra muhafazası için bir çeşit alçı taşı ile kaplandığını gören Desmazures'in bu taştaki ayrıntı dikkatini çeker. İçerisinde başka maddelerin olduğunu ve bunun incelenmesi gerektiğini düşünür. Ancak Osmanlı topraklarında bu incelemeyi yapabilecek gerekli araçgereçler olmadığından bu parçalardan birini Paris'e gönderir. Yapılan incelemeler neticesinde bu maddenin \%40 ila \%44 oranında borik asit içeren kireç biboratı olduğu anlaşılır. Bu madde henüz Osmanlı kimyacıları tarafından bilinmeyen ve şimdiye kadar 
yapılan ticari anlaşmaların hiçbirine dâhil olmayan bir maddedir. Bundan sonra Desmazures ve Groppler borasitin geldiği alçı sıva alanını aramak için ajan Ratysnki'yi görevlendirmişlerdir (Cuinet, IV, 1894: 18). Böylece bor madeninin çıktığı sahayı tespit eden Groppler ve Desmazures başlangıçta Osmanlı Devleti'ne bulunan yeni madenden hiç bahsetmeden borasitin bulunduğu alçı madenini kiralamışlardır (Sayan, 2016: 12-13). Ardından buradaki imtiyaz sahibini devre dışı bırakarak alçı taşı çıkarmak üzere bir imtiyaz talebinde bulunmuşlardır. Desmazures ve Groppler'e 37,5 dönümlük alanda 20 yıllık bir imtiyaz verilmiştir ( BOA, ŞD. 237/17, 8 Safer 1287, 10 Mayıs 1870: Cuinet, IV, 1894: 18) Bu ilk imtiyaz 150 hektarlık alanı kapsayan girişimin başlangıcı olmuştur. Aslında madenin çıkarılıp Avrupa'ya ihracı çok daha öncelere aittir. Zira 1865 yılında Desmazures, Compaigne Industrielle şirketini kurmuştur. Böylece Compaigne Industrielle Desmazures çalışmalarıyla Sultançayırı'ndan çıkarılan borasit cevheri 1868 yılında Avrupa pazarında tanınmıştır (Sayan, 2016: 16) Osmanlı Devleti ise 1874 yılında Bandırma rüsumat müdürünün yeni bir cevherin alçı madeni adı altında ihraç edildiği bilgisini merkeze bildirmesi üzerine konuyu araştırmaya başlamıştır (Sayan, 2016: 19-20). Daha sonra bölgede bor madenleri için Osmanlı tebaasından Şirinyan ve yabancı devletler tebaalarından, Lorando, Giove, Hanson ve Groppler ile Desmazures'in şirketi arasında bir rekabet yaşanmıştır. Fakat bu rekabet kendi aleyhlerine olduğundan ilk imtiyaz sahipleri ile Lorando, Giove, Hanson birleşerek "Borax Company" adlı şirketi kurmuşlardır. Bu birleşme 1887 yıllında padişah iradesi ile kabul edilmiştir (Cuinet, IV, 1894: 19).

Cuinet, Sultançayırı'ndaki maden şirketinde 1894 yılında bir Fransız mühendis başkanlığında 200 işçinin çalıştığını, işletmelerinde makinalar bulunduğunu kaydetmiştir. Bunun karşılığında hükümete gelirlerinden \%16 ödemektedirler. Aynı nahiyede Demirkapı'da bulunan borasit madeni imtiyazı Fuad Paşa'ya verilmiştir (BOA, İ.DH. 1154/90242, 26 Muharrem 1307, 22 Eylül 1889; Cuinet, IV, 1894: 19). Fuad Paşa ise imtiyazı merkezi Paris'te olan Fransız Lyon Şirketine devretmiştir. Cuinet bu madenin henüz çıkarılmadığını aktarmıştır (Cuinet, IV, 1894: 19). Balıkesir madenlerinin çıkarılması, imtiyazların verilmesi, uzatılması gibi hususlarda arşivde bol miktarda vesika mevcuttur. $\mathrm{Bu}$ belgeler bölgedeki yoğun rekabeti de göstermektedir. Bunların hepsinin birden değerlendirilmesi makalenin boyutunu aşacağından çalışmaya dâhil edilmemiştir.

\section{Sonuç}

Cuinet, dört ciltlik eserinde bilgilerini aktarırken Osmanlı idarî taksimatına uygun bir şekilde önce vilayetler hakkında bilgi vermiştir. Burada öncelikle vilayetin sınırlarını çizmiştir. Daha sonrasında vilayete bağlı bulunan sancak, kaza, nahiye ve köy sayılarını istatistiksel olarak verdikten sonra vilayet yönetimi, kamu binaları, ibadethaneler, dükkânlar gibi yapıların adedi hakkında bilgiler sunmuştur. Ardından başta Müslim ve gayrimüslim nüfus oranları olmak üzere, sivil, ticarî, askerî ve dinî yapılarla birlikte, eğitim binalarını ve bu binalarda okuyan Müslim ve gayrimüslim öğrenci sayısını, bölgede yetiştirilen zirâ̂, hayvan ve endüstri ürünlerinin yıllık üretim miktarlarını, bunlardan elde edilen yıllık gelirleri, yerleşimlere ait toplam yıllık gelir miktarını göstermiştir. Bölgelerde yer alan varsa ormanlar, yeraltı kaynakları, kaplıcalar hakkında da detaylı bilgiler aktarmıştır. Aynı sıralamaları, sancaklar ve kazalarda da tekrarlamıştır. Böylece Cuinet'in verdiği bilgilerle Osmanlı Devleti'nin Anadolu topraklarında, Arap yarımadasında, Girit ve Cezayir-i Bahr-i Sefid gibi adalar kısmında toplum yapısı, ekonomik faaliyetler, yeraltı kaynakları, mali yapı 
hakkında çok değerli bilgileri edinmek mümkün olabilmektedir. Aslında Cuinet, alacaklı kurumun bir çalışanı olarak bölgede para edebilecek ne var ise kayıt altına almıştır. Böylece Osmanlı Devleti'nin aslında bir anlamda mali potansiyelini de ortaya koymuştur. Özellikle Balıkesir ile ilgili verdiği bilgilere bakıldığında çoğunlukla bu dönemde vilayet hakkında yine detaylı bilgiler sunan Hüdavendigar Vilayet Salnamesinden faydalandığ görülmektedir. Cuinet buradan aldığı bilgileri toparlayıp kendi elde ettiği verilerle bütünleştirmiştir. Bu bakımdan Cuinet'in Balıkesir hakkında verdiği bilgilerin salnameleri tamamlayıcı bir özelliği olduğunu söylemek mümkündür. Her ne kadar Cuinet'in bir Fransız ve Duyun-1 Umumiye İdaresi Genel Sekreteri olmasından dolayı verdiği bilgilerin güvenirliği konusunda şüpheleri olanlar bulunsa da en azından Balıkesir için herhangi bir taraflılık gütmediği söylenebilir. Hatta Şemseddin Sâmî'nin 1896 yılında basılan eserinde Karesi Sancağına ait bilgiler Cuinet'in eseri ile birebir örtüşmektedir. Osmanlı makamlarının da özellikle nüfus konusunda iddialarına dayanak olarak Cuinet'in eserini göstermesi de bu düşünceyi destekler niteliktedir.

Bu çalışmada Cuinet'in verdiği bilgilerden yola çıkılarak 1890'lı yıllarda Balıkesir'in sosyoekonomik yapısı ortaya konulmaya çalışılmıştır. O dönem sancak olan Karesi ve merkezi Balıkesir bu çalışmanın konusudur. Karesi Sancağının diğer kazaları Ayvalık, KemerEdremit, Edremit, Erdek, Gönen, Bandırma, Bigadiç ve Sındırgı bu çalışmaya dâhil edilmemiştir. Cuinet, eserinde bazen vilayet genelinde anlattığ kazada da değinmesi gerektiğinde daha önceden bahsettiği kısma atıfta bulunarak geçiştirmiştir. Özellikle Balıkesir madenleri konusunda Bursa Vilayetini anlatırken detaylı bir biçimde ele aldığından Balıkesir kısmına geldiğinde oraya atıf yapmıştır. Bu bilgiler oldukça özgün olmakla birlikte taşıdığı önem dolayısıyla çalışma kısmına bu sayfalarda yer alan Balıkesir ile ilgili kısmı dâhil edilmiştir. Sonuç olarak elde edilen veriler genel olarak değerlendirildiğinde Cuinet'in verdiği bilgiler vasıtasıyla bu dönemde Karesi Sancağının Osmanlı ekonomisinde önemli bir yere sahip olduğu anlaşılmaktadır. Dış borçlarını ödeyemediği ve Düyûn-1 Umumiye İdaresi'nin kuruluşu ile mali anlamda Avrupa devletlerinin baskısının hissedildiği, yüklü miktarda borç ödemeye çalıştığı bir dönemde buradan elde edilen tütün, içki, madenler gibi gelir kalemleri bir hayli önem arz etmektedir. Özellikle Anadolu'da ilk olarak bulunan borasit madeni hem Osmanlı ekonomisi hem de yörenin ekonomisinde bir canlanma meydana getirmekle birlikte bölgede Batılı devletlerarasında mücadelenin yaşandığı bir sürece de girilmiştir. Bölgeden madenin çıkarılması, çıkarıldıktan sonra ihraç olunmak üzere kıyı şeridine ulaştırılması gibi iş ve işlemler ekonomik anlamda da bir hareketlilik meydana getirmiştir. Bunların daha net bir şekilde ortaya konulabilmesi için Osmanlı döneminde yayınlanan diğer istatistikî bilgiler, Cuinet'in verdikleri ile kıyaslanmak suretiyle bir değerlendirmeye tabi tutulmalıdır. Böylece yıllar içerisinde Balıkesir' de meydana gelen sosyal, iktisadî, eğitim gibi konularda değişimler takip edilebilir ve Cuinet'in verdiği bilgilerin bir sağlaması yapılabilir. Bu anlamda çalışmanın yapılacak yeni çalışmalara bir kaynak mahiyetinde olacağı düşünülmektedir. 


\section{Kaynakça}

\section{Arşiv Belgeleri}

\section{Cumhhurbaşkanlığı Osmanlı Arşivi (BOA)}

Dahiliye Nezareti Kalem-i Mahsus (DH.KMS.), 51/9.

Dahiliye Nezareti Mektubî Kalemi (DH.MKT.), 1824/20; 1804/36.

İrade Dâhiliye Nezareti (İ.DH.), 1154/90242.

Kâmil Kepeci Defterleri (KK.d.), 6479.

Nüfus Defterleri (NFSd.), 1262.

Şura-yı Devlet (ŞD.), 237/17.

\section{Salnameler}

Hüdavendigar Vilayet Salnamesi, Def'a 18, sene 1307 (1891-1892).

Hüdavendigar Vilayet Salnamesi, Def'a 19, sene 1310 (1894-1895).

\section{Yayımlanmış Eserler}

Akkaya, B. (2013). "Geçmişten Günümüze Türk Polis Teşkilatında Rütbeler”, Turkish Studies, 8/5, s. 59-72. DOI: $10.7827 /$ TurkishStudies. 4757

Ali Tevfik (1308). Memalik-i Osmaniye Coğrafyası, İstanbul: Karabet Matbaası.

Atam, Ş., Candeğer, Ü. (2019). "Vital Cuinet'e Göre XIX. Yüzyil Sonunda Antakya", HATAY Anavatana Katılışının 80. Yıl Armă̆anı, edt. Ahmet Gündüz, Haydar Çoruh, Süleyman Hatipoğlu, İstanbul: Hiperyayın.

Baykara, T. (2000). Anadolu'nun Tarihî Coğrafyasına Giriş I Anadolu'nun İdari Taksimatı, Ankara: Türk Kültürünü Araştırma Enstitüsü Yayınları,.

Birdal, M. (2010). The Political Economy of Ottoman Public Debt Insolvency and European Financial Control in The Late Nineteenth Century, New York.

Bölükbaşı, Ö. F., (2005). Tezyid-i Varidat ve Tenkih-i Masarifat II. Abdülhamid Döneminde Mali İdare, İstanbul: Osmanlı Bankası Arşiv ve Araştırma Merkezi Yayınları.

Cuinet, V. (1894). La Turquie d'Asie, Géographie Administrative Statistique Descriptive et Raisonnée de L'Asie Mineure, vol. I-IV, Paris: Ernest Leroux.

Çadırcı, M. (1997). Tanzimat Döneminde Anadolu Kentlerinin Sosyal ve Ekonomik Yapısı, Türk Ankara: Tarih Kurumu Yayınları,

Çakmak, Y . (2020). "Şemseddin Sâmî Ve Vital Cuınet'in Çalışmalarında Erzincan”, Munzur Üniversitesi Sosyal Bilimler Dergisi (MÜSBİD), 9/1, s. 22-37.

Çelik, Ş. (2012). “Evliya Çelebi'nin Bandırma, Aydıncık (Edincik), ve Erdek İle İlgili Verdiği Bilgiler ve Bunların Değeri", Balıkesir Üniversitesi Sosyal Bilimler Enstitüsü Dergisi, 15/28-1, s. $67-81$.

Gülmez, M. (1983). "Polis Örgütünün İlk Kuruluş Belgesi ve Kaynağı”, Amme İdaresi Dergisi, 16/4, s. 3-15. 
Güloğlu, Y. (2010). “Orman Mülkiyetinin Doğuşu ve Osmanlı Devletinde Tanzimat Dönemine Kadar Ormanlarla İlgili Yapılan Yasal Düzenlemeler", Kastamonu Üniversitesi Orman Fakültesi Dergisi, 10/2, s. 180-194.

Gürsoy, B. (1984). "100. Yılında Düyun-u Umumiye İdaresi Üzerinde Bir Değerlendirme”, İstanbul Üniversitesi İktisat Fakültesi Ord. Prof. Şükrü Baban'a Armă̆an, İstanbul, s. 17-59.

Issawi C. (1982). An Economic History of the Middle East and North Africa, New York: Columbia University Press.

Küçük, C. ve Ertüzün T. (1994). “Düyûn-1 Umûmiye”, TDV İslâm Ansiklopedisi, X, Ankara, s. 58-62.

Koç, B. (2005). “1870 Orman Nizamnamesi'nin Osmanlı Ormancılığına Katkısı Üzerine Bazı Notlar" Tarih Araştırmaları Dergisi, 24/37, s. 231-257.

Koç, Z. (2014). Karesi Sancağına Yapılan Göçler (1860-1890), (Yayımlanmamış Yüksek Lisans Tezi, Balıkesir Üniversitesi, Sosyal Bilimler Enstitüsü, Balıkesir). Erişim adresi: http://tez2.yok.gov.tr/

Kodaman, B. ve İpek, N. (2000). “Balkanlar. Girit ve Kafkaslarda Anadolu'ya Yönelik Göçler ve Göçmen İsken Birimlerinin Kuruluşu (1878-1912)”, Erdem, 12/35, 377-417.

Mutaf, A. (1997). Salnâmelerde Karesi Sancağı (1847-1922), Balıkesir.

Öntuğ, M. M. (2006). “Balıkesir'deki Ermeni Kilisesi ve Mektep Açma Faaliyetleri”, OTAM, 19, s. 343-364.

Sayan, M. (2016). Karesi Sancağında Bor Madeni İşletmeciliği, (Yayımlanmamış Yüksek Lisans Tezi, Marmara Üniversitesi Türkiyat Araştırmaları Enstitüsü, İstanbul). Erişim adresi: http://tez2.yok.gov.tr/

Pamuk, Ş. (2018). Osmanlı Ekonomisinde Bă̆ımlılık ve Büyüme (1820-1913), , İstanbul: Türkiye İş Bankası Yayınları.

Şemseddin Sâmî, (1306/1889). Kâmûsu'l - A'lâm, 2, İstanbul: Mihran Matbaas1.

Şemseddin Sâmî, (1314/1896). Kâmûsu'l - A'lâm, 5, İstanbul: Mihran Matbaas1.

Şimşir, N. (2004). Osmanlı Araştırmaları (Makaleler I), İstanbul: IQ Yayınları.

Tellioğlu, İ. (1998). "Vital Cuinet'e Göre Karadeniz Bölgesinin Nüfusu”, Fırat Üniversitesi Ilahiyat Fakültesi Dergisi, 3, s. 95-102.

Toruk, F. (2009). “Fransız Gezgin Vıtal Cuınet'in Gözüyle Çankırı”, Belleten, LXXIII/ 268, s. 721-740.

Töreli, T. (2020). “Düyun-u Umumiye Genel Sekreteri Vital Cuinet'in 1891'de Malatya Sancağ 1 Üzerine Tespitleri” Dokuz Eylül Üniversitesi Sosyal Bilimler Enstitüsü Dergisi, 22/2, s. 763-769.

Yağcl, Z. G. ve Genç S. (2013). H. 1256/M. 1840-41 Tarihli Balıkesir Nüfus Defteri (Değerlendirme ve Transkripsiyon), Balıkesir: Balıkesir Belediyesi Kent Arşivleri Yayınları. 